\title{
Local representations of change and conservation of the riparian forests along the São Francisco River (Northeast Brazil)
}

\author{
Taline Cristina Silva a , Marcelo Alves Ramos ${ }^{\text {b }}$, Maria Luiza Schwarz ${ }^{\mathrm{c}}$, Ivan André Alvarez ${ }^{\mathrm{d}}$, \\ Lúcia Helena Piedade Kill ${ }^{\mathrm{d}}$, Ulysses Paulino Albuquerque ${ }^{\mathrm{a}, *}$ \\ a Laboratório de Etnobiologia Aplicada e Teórica, Departamento de Biologia, Área de Botânica, Universidade Federal Rural de Pernambuco, Brazil \\ b Universidade de Pernambuco, Campo Mata Norte, Brazil \\ c Universidade Federal de Campina Grande, Campus Cajazeiras, Brazil \\ d Empresa Brasileira de pesquisa Agropecuária, Brazil
}

\section{A R T I C L E I N F O}

\section{Article history:}

Received 24 May 2013

Received in revised form 7 November 2013

Accepted 26 November 2013

Available online $\mathrm{xxxx}$

\section{Keywords:}

Riparian forest

Landscape modification

Environmental perception

Ethnobiology

\begin{abstract}
A B S T R A C T
Investigations of local representations about the environment allow for the elucidation of historical landscape transformation and the elaboration of strategies for environmental conservation. Thus, this study aimed to answer the following questions. How does the local population represent the possible changes in riparian vegetation over time? What historical events were responsible for these possible changes? How does the local population represent concerns related to the use and maintenance of riparian vegetation? This study was carried out with 87 informants from three communities: two rural ex-settlement communities and one quilombo in Northeastern Brazil. According to the informants, there were changes in the riparian vegetation. The main causes of these changes include the type of agriculture practiced in the region and the building of a large dam to provide water to the city of Sobradinho in the state of Bahia. However, there was no significant difference between the number of informants who said that the changes were for the worse and those who said that they were for the better. In addition, the respondents reported an increase in the abundance of exotic species and a decrease in the abundance of native species. Thus, the importance of including this group of people in the process of the forest restoration that will occur in the region is emphasized because they possess information about the past vegetation changes and their causes. They can also indicate which species should be prioritized for replanting according to their usage needs and they understand the importance of conserving riparian vegetation.
\end{abstract}

(c) 2014 Elsevier B.V. All rights reserved.

\section{Introduction}

Changes to natural environments are occurring in different parts of the world. For example, Santiago et al. (2002) report that natural landscapes in Brazil are undergoing rapid change due to increasing urban development, which particularly affects native vegetation. Similarly, the riparian vegetation in the São Francisco River Basin in the Caatinga, a savanna-like domain in Brazil, has been undergoing constant change due to inappropriate land use, pollution from pesticides, desertification caused by the removal of native vegetation for agricultural development and disorganized exploitation of various timber and non-timber products without reforestation (Campello et al., 1999).

Local people develop close links with riparian natural resources. By using these resources and managing the ecosystem, they understand and are directly involved in the process of landscape change (Bell, 2001). To understand the processes of degradation and thus recover

* Corresponding author at: Av. Dom Manoel de Medeiros s/n, Dois Irmãos, CEP: 52171 900, Recife, Pernambuco, Brazil. Tel.: +55 8133206350.

E-mail address: upa@db.ufrpe.br (U.P. Albuquerque). the vegetation of these areas, it is believed that local people must become integral participants in ecosystem restoration. Importantly, this participation will be beneficial to the environment if these people understand environmental problems and are willing to contribute to their solutions. Therefore, the first step toward the process of increasing local knowledge and promoting environmental citizenship is to investigate the perceptions of local people and access their "vision" of the surrounding environment (Fernandes et al., 2006). Previous works, such as by Lykke (2000) and Xu et al. (2006), have shown that by accessing local representations of the native vegetation, it is possible to identify changes in the landscape. Local people may be able to indicate which species have declined over the years, and this information may be used to support future reforestation projects. Moreover, as illustrated by Tabuti (2007), in addition to reporting which species have declined, people can identify the causes associated with these declines and landscape modification and reflect on their own attitudes toward the environment. Therefore, this study aims to generate information that will contribute to the recovery of degraded riparian vegetation on the banks the São Francisco River, which is important for agricultural irrigation and the survival of local populations. This work is part of a project 
by a Brazilian agricultural research company to recover riparian forests. This company intends to undertake reforestation focused on the species most used by the local people, and it also seeks to involve participants in this study through environmental education.

This study addresses the following questions: How does the local population represent changes to riparian vegetation over time? What historical events were responsible for these changes? How does the local population represent issues related to the use and conservation of riparian vegetation?

In this work, the term "representation" will be used to replace the term "perception" because "perception" only refers to what is perceived through the senses (Gumuchian and Marois, 2000). Moreover, Cavalcante and Maciel (2008) argue that there is a difference between what is perceived and what can be expressed.

\section{Materials and methods}

\subsection{Study area}

This work was conducted in 2009 in the $117,351 \mathrm{~km}^{2}$ valley region of the São Francisco River (Fig. 1), which covers the states of Bahia (BA), Pernambuco (PE), Alagoas (AL) and Sergipe (SE) in Northeast Brazil. This region has a population of approximately 2.48 million inhabitants (IBGE, 2008). The São Francisco River Basin is the most highly populated, semi-arid region in the world. Some of the micro-regions of the São Francisco River basin cover municipalities that are mostly occupied by small farms and have some of the lowest Human Development Index (HDI) ratings in Brazil. Approximately $80 \%$ of the private landholdings are 50 ha in size.

Three communities in two municipalities, Curaçá in Bahia and Lagoa Grande in Pernambuco, participated in the study. Both cities are part of the Integrated Network Development Region (RIDE) of Petrolina and Juazeiro (Fig. 1 and Table 1). The RIDE was established in 2002 by the Ministry of National Integration and includes 610,000 inhabitants over $34,000 \mathrm{~km}^{2}$, which spans four municipalities in Pernambuco and four in Bahia. It is important to note that all of the people from the three communities who participated in the study were asked to sign an informed consent (IC) form to authorize their participation in the research in accordance with Resolution No. 196/96 of the National Health Council. The three communities were chosen for this study because they will be part of a forest restoration project that is being developed by Semi-Arid Embrapa, a Brazilian agricultural research company. Additional inclusion criteria for the communities included their reliance on the use of resources from the riparian vegetation communities, political organization through community leaders and location in environmentally degraded areas.

Each of the participating communities has different environmental and socio-cultural characteristics, such as the type of land use. All of these people live in areas adjacent to the São Francisco River and generally share the use of common resources (Fig. 2A).

The community of Ouro Verde (Fig. 2B) is located in Lagoa Grande in Pernambuco. The settlers live in a rural area that was expropriated by the federal government but that now belongs to them. The community was initially formed in 1987 by 15 families and is currently composed of 100 families from different states in Northeast Brazil. In this community, the families who live closest to the river grow grapes and mangos and use river water for irrigation. Field observations indicate that the main economic activity is winemaking, and each family has a plot of land for this purpose. The community contains a public school (1st through 4th grade), 1 Protestant church and 1 Catholic church and a community center. The president of this community association was contacted before the survey was conducted. In this community, a total of 54 heads of family ( 32 women and 22 men), aged between 20 and 71 years, participated in the survey. This sample is not representative of the total number of families in the community because it was only possible to interview only the heads of family who were willing to participate in the reforestation project and who were also available at the time of the survey. This explanation also applies to the total respondents in the other communities described below. In the city of Curaçá in Bahia, historical data have been recorded from the sixteenth century to the arrival of the Jesuit Luis de Gran, who came to indoctrinate the Indian inhabitants of the Valley of São Francisco (IBGE, 2008). In this area, the rural settlement of Grapiúna was part of the study (Fig. 2C). Twelve families currently live in the settlement although there were 50 families when it was founded in 1987. The community's primary means of subsistence is farming near the river, and each family is entitled to an 8 acre plot of land for planting. In this community, it was possible to conduct interviews with 10 heads of family ( 7 women and 3 men).

The community of Jatobá, which is located in the same municipality (Curaçá), is recognized by themselves as a quilombo, a relatively isolated community inhabited by the descendants of African slaves, and according to the older residents, was founded in 1909 (Fig. 2D). Agriculture is the main economic activity in the community, and there is a communal plot of land where most of the people plant vegetables. This community works as a cooperative where workers who are part of the residents' association equally invest in agricultural production and share in the profits. According to local health officials, there are 35 families in this community. A total of 23 heads of family (17 women and 6 men), aged between 18 and 83 years, were recruited for the study. Despite not having witnessed changes in the vegetation for 20 years, younger informants were included in the survey because they had information from the older people. Furthermore, we believe that questioning these informants provokes reflection on their attitudes towards the environment and contributes to the conservation of natural resources.

There are a Catholic church, a municipal elementary school and a neighborhood association, where residents and members of the cooperative meet monthly.

\subsection{Data collection}

\subsubsection{Semi-structured interviews and free list}

Semi-structured interviews with residents of the three communities were used to verify representations of local changes in the landscape, to record how the historical events that influenced these changes were represented and to record the representations of the conservation and utility of riparian vegetation, known by the respondents as the "bush by the river". A checklist interview (Minayo, 1993) was also used to gather information about local changes in the landscape and included a visual component that consisted of a set of three pairs of photographs of the region (Fig. 3). Two photographs were shown that depicted the non-degraded riparian forest areas (Fig. 3A and B), two showed semidegraded riparian vegetation areas (Fig. 3 C and D), and two showed highly degraded riparian vegetation areas (Fig. 3E and F). Participants were asked to look at the images and indicate which represented the riparian vegetation in the community 20 years ago, 10 years ago and today.

A free-list technique, which seeks information about specific cultural phenomena, was used to record local representations of species diversity. The free-list technique is based on the principle that culturally significant elements will appear on a list in order of importance. This technique then calculates the frequency and the ranking at which a plant is cited (Albuquerque et al., 2014). Moreover, socioeconomic data such as age, gender, duration of residence and education were also collected.

\subsubsection{Participatory methods}

To determine representations of changes to the landscape and the abundance of plant resources, respondents from the communities of Jatobá and Ouro Verde participated in a collective meeting in which two types of participatory methods were used. It is important to note 



Fig. 1. Location of the two municipalities that participated in the study in the states of Pernambuco and Bahia, Northeast Brazil (by Franklin Silva).

that it was not possible to use these methods for the study at Grapiúna as informants were unable to participate in a collective meeting.

The first participatory method consisted of building a historical chart to show representations of changes in the abundance of the most important species in the free-list (Sieber et al., 2014). Upon completion of all the interviews in the Jatobá and Ouro Verde communities, we calculated the 10 most prominent species indicated by the free-lists using the software Anthropac 4.0 (Borgatti and Natick, 1996). The calculation considers the order and frequency at which each species was mentioned. For each of the 10 species, participants were prompted to indicate their abundance over the last 20 years, 10 years and today. For each time interval, resources were represented by symbols, paper trees, where 10 paper trees indicated the maximum abundance of the species. A phytosociological study carried out by a Semi-Arid Embrapa survey team allowed for the identification of specimens after collection. In that survey, three tracts were established on each property with the

Table 1

General data for the three communities studied in the states of Pernambuco and Bahia, Sao Francisco River Basin, Northeast Brazil.

\begin{tabular}{|c|c|c|c|c|}
\hline Community & State/city & Municipality extension & Latitude/longitude & $\begin{array}{l}\text { No. heads of family } \\
\text { interviewed }\end{array}$ \\
\hline Ouro Verde & Pernambuco/Lagoa Grande & $1852 \mathrm{~km}$ & $08^{\circ} 59^{\prime} 49^{\prime \prime} \mathrm{S} 40^{\circ} 16^{\prime} 19^{\prime \prime} \mathrm{W}$ & 54 \\
\hline Grapiúna & Bahia/Curaçá & $6442.190 \mathrm{~km}$ & $08^{\circ} 59^{\prime} 31^{\prime \prime} \mathrm{S} 39^{\circ} 54^{\prime} 28^{\prime \prime} \mathrm{W}$ & 10 \\
\hline Jatobá & Bahia/Curaçá & $6442.190 \mathrm{~km}$ & $08^{\circ} 59^{\prime} 31^{\prime \prime} \mathrm{S} 39^{\circ} 54^{\prime} 28^{\prime \prime} \mathrm{W}$ & 23 \\
\hline
\end{tabular}




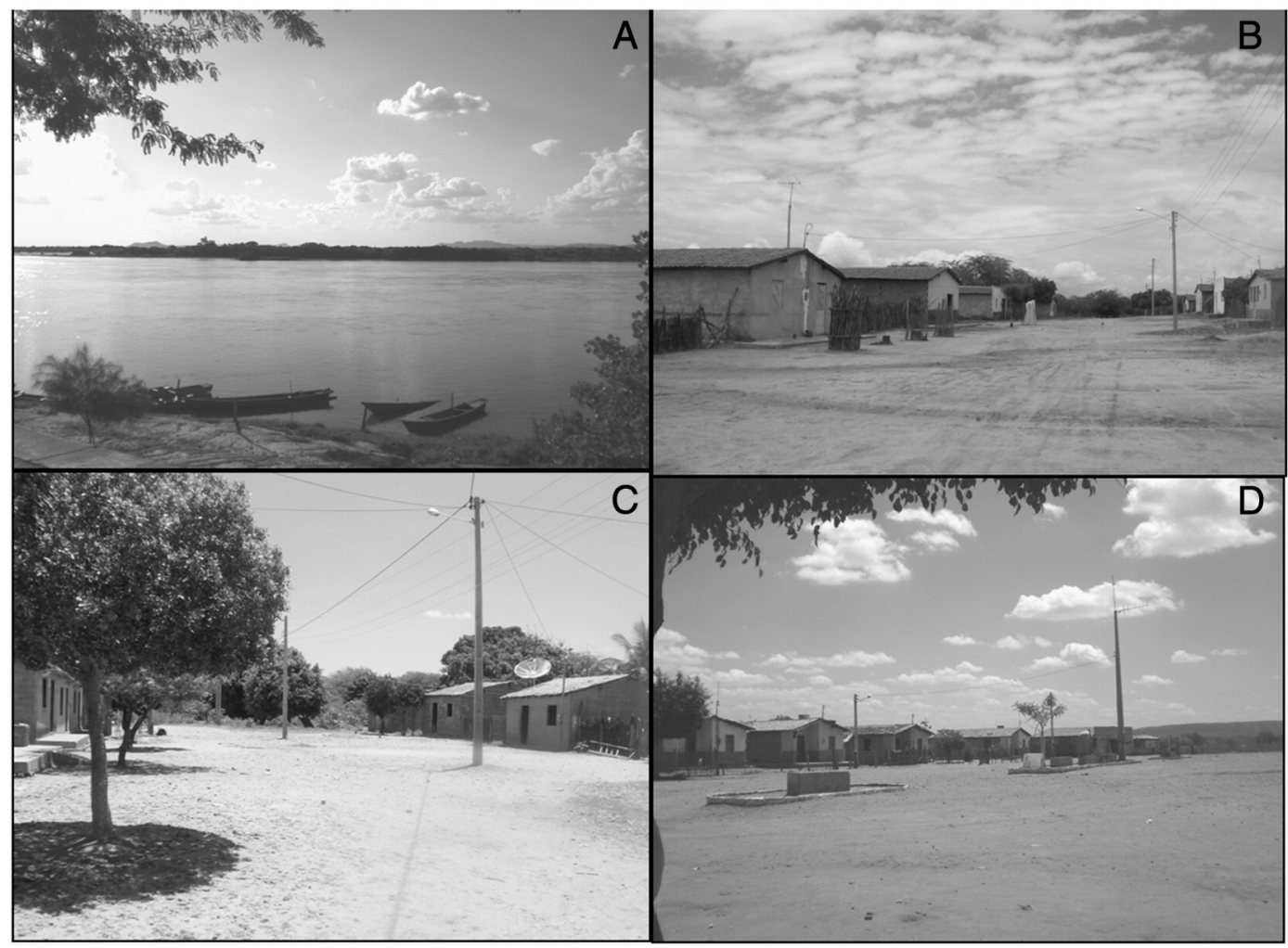


the city of Curaçá, BA.

aid of a 50-meter tape. The first tract was located on the riverbank, and the second and third tracts were located 40 and $90 \mathrm{~m}$ from the bank, respectively. Along each tract, $10 \times 20 \mathrm{~m}$ plots separated by $10 \mathrm{~m}$ were inventoried. Subsequently, the height and diameter at breast height (DBH) of all individual trees with a DBH less than $3 \mathrm{~cm}$ were measured using calipers and measuring sticks. Species less than $3 \mathrm{~cm}$ in diameter were counted and considered to be regenerative growth. There were 27 plots in Ouro Verde, 24 in Jatobá and 27 in Grapiúna.

The second participatory method was the construction of a timeline (Sieber et al., 2014) that was used to record the historical events that were locally perceived as influencing possible modifications to the landscape. This step consisted of asking workshop participants to note significant changes in the community's past that could explain the present use of natural spaces and specific vegetation resources. Informants were encouraged to discuss and note the key events that changed the landscape in the region. Starting points for these discussions were the founding of the community, the identities of the first people to arrive in the community and the events that were the most important up to the present day. Participants were also asked about changes that occurred in the landscape over time and their possible causes. A vertical line was drawn on a piece of cardboard to represent the timeline of events (Sieber et al., 2014). All information was recorded on a preprepared form (Sheil et al., 2004).

\subsection{Data analyses}

To assess local representations of changes in the riparian vegetation, the chi-squared test was used in BioStat 5.0 software (Ayres et al., 2007). The test was used to verify the existence of significant differences between the number of informants who said that the vegetation had changed and those who said it had not and between responses stating that the changes had been for the better versus for the worse (Ayres et al., 2007). The non-parametric G-test was used to determine whether there were significant differences between the representations of changes in the riparian vegetation by younger informants (18 30 years) versus older informants (above 30 years).

Subsequently, collective subject discourse analysis (Lefevre, 2005) was used on informants' justification of vegetation change as either for better or for worse. Key phrases were extracted from each answer, and similar central ideas were then grouped together to build the collective discourse.

To determine when vegetation changes were initiated in each community, we analyzed the photographs that the respondents indicated as showing changes 20 and 10 years ago and today. To supplement this information, we used vegetation cover data from Landsat TM5 satellite images collected in September of 1989, 1997 and 2009 (543 RGB color combination supplied by Semi-Arid Embrapa) to identify changes in the region. The vegetation inventory made it possible to identify phytosociological parameters, such as relative density, and the importance values of the most prominent species in the free-lists from the three communities.

These data allowed a further comparison to the abundances represented by the respondents in the Ouro Verde and Jatobá communities. However, the aim of this comparison was not to validate or invalidate the two datasets but rather to highlight similarities and differences between them.

\section{Results}

\subsection{Local representations of changes in riparian vegetation}

\subsubsection{Ouro Verde community}

Sixty-three percent of the 54 respondents in this community reported that changes in the riparian vegetation had occurred in the region while $37 \%$ said that the vegetation had not changed. There was a significant difference between the number of people who said there were changes and those who said there were no changes ( $p=0.093, \chi^{2}=0.0124$ ). In addition, there were no significant differences between younger and older 


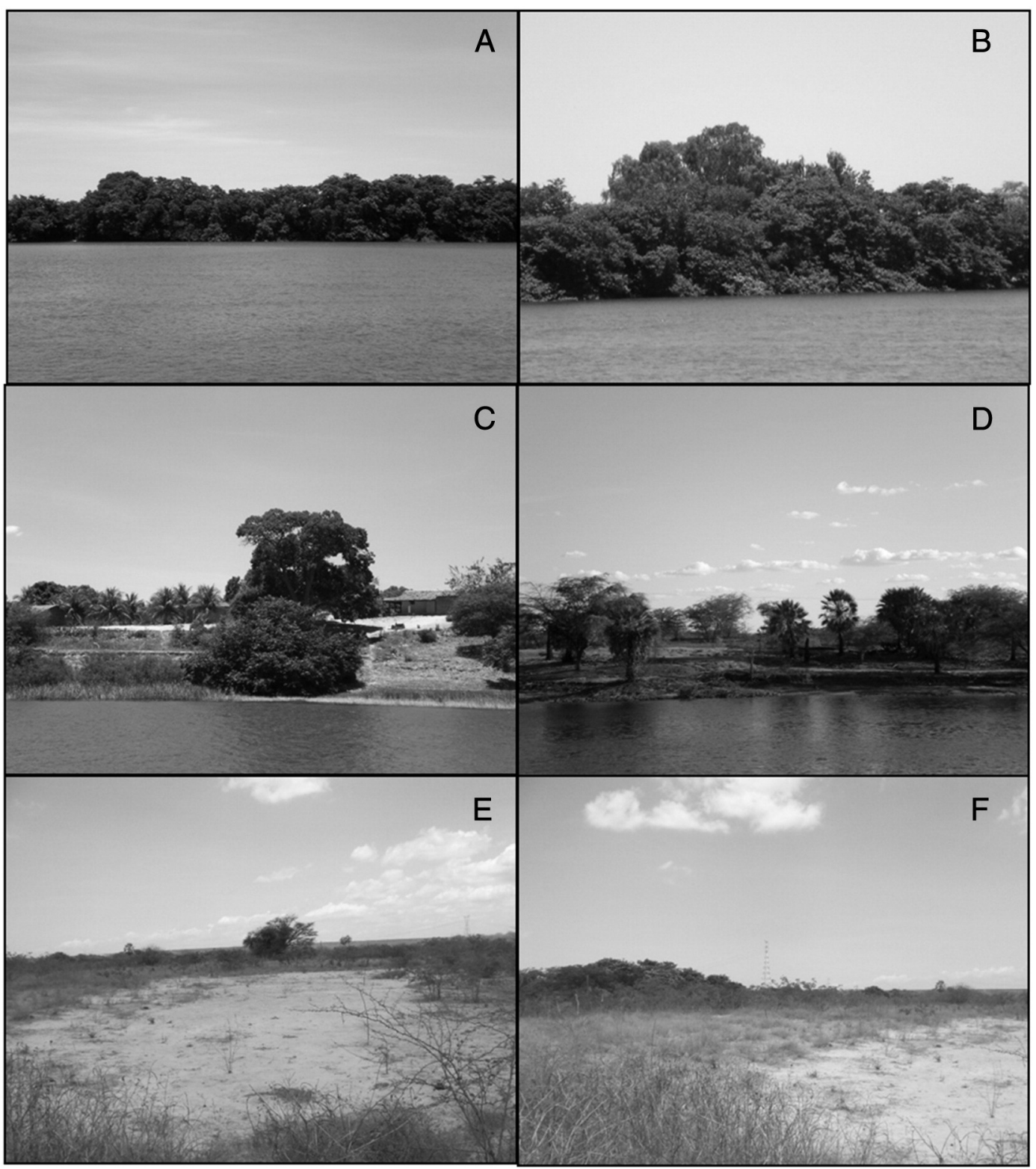

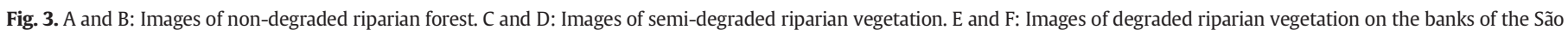
Francisco River, Northeast Brazil.

respondents concerning changes in the vegetation $(\mathrm{p}=0.696$; $\mathrm{G}$-test $=$ 0544). Fifty-six percent of the respondents indicated that the changes were for the worse, and $44 \%$ indicated that they were for the better. When encouraged to justify their answers about why changes had been for the worse, participants presented the following arguments: $64 \%$ responded that the riparian vegetation previously had more trees, 34\% attributed the changes to human-caused destruction, and $2 \%$ reported that the diversity of plants had formerly been greater. Through the answers presented by this group of informants, it was possible to build the following collective discourse:

"There were more trees; now forests have decreased. Before, it was all forest; now, the river is deforested. There are fewer plants. Previously, we obtained tool cable more easily. Now, they have been cut, and there are fewer plants because people have destroyed them. There has been exploitation. Previously, there were more species."

From the central topics extracted from the key expressions of those informants that reported a decline in riparian vegetation, it was possible to detect their perceptions of the decline of plant species over time and the possible causes of this change.

From the $44 \%$ of respondents who said that the riparian vegetation had changed for the better, the following arguments were highlighted: $58 \%$ stated that there are more plants today, $28 \%$ said that people are protecting the vegetation more, and $14 \%$ reported that more trees have been planted. The following collective discourse was built:

"There are more plants and more trees. The forest is now full. People do not cut sticks from the riverbank. We no longer grow crops there. People have planted for shade. They are protecting more. They have planted more plants and more trees."

From the central topics extracted from the key expressions of the informants' responses, an increase in the conservation of riparian vegetation and the abundance of these plant resources was observed. However, this perception of increased abundance in plants could be associated with the presence of exotic species as will be observed later. For these informants, the concept of protected vegetation is the same as 
conservation, so the justification that fewer resources are used today means that the vegetation is more protected.

Another aim of the semi-structured interviews was to determine when such environmental changes began. There appeared to be no consensus among the informants as $24 \%$ said that changes had occurred less than five years ago, $24 \%$ said that changes had occurred between six and ten years ago, 31\% indicated that changes were initiated between 15 and 20 years ago, and $21 \%$ said that changes began more than 20 years ago. Additionally, in the checklist interviews, $80 \%$ of the informants indicated that the most common type of land cover in the study region 20 years ago was the non-degraded riparian vegetation. Apparently, changes were primarily initiated at least 10 years ago as $42 \%$ of the respondents indicated that the images of semi-degraded riparian vegetation were correct for this period. When encouraged to indicate the image that best represented the current state of the riparian vegetation, $44 \%$ chose images of non-degraded riparian vegetation. The indication of these images by the respondents suggests that, although the landscape has gone through a process of change, the riparian vegetation in these areas is currently in a state of regeneration. These results confirm preliminary data provided by Semi-Arid Embrapa on vegetation cover in the town of Lagoa Grande. According to this survey, vegetation cover in the region amounted to approximately $72.06 \%$ in the 1980 s; there was a decrease to $58.31 \%$ in the 1990 s; and currently, the vegetation coverage is $59.63 \%$.

In addition, all of the informants in the community were invited to participate in the survey. However, only 14 people ( 7 men and 7 women), aged between 47 and 69 years, were willing to cooperate. It was possible to build a historical graph from the participatory methods (Fig. 4), and the graph indicated the decline and abundance of the 10 most prominent species obtained from the free-lists, which were created by all of the research participants, from 20 years ago, 10 years ago and today (Table 2).

The results showed that the participants believe that most of the species of riparian vegetation in this region have increased or decreased in abundance. For example, participants reported that there was a significant increase in the abundance of species such as Prosopis juliflora (Sw.) DC. (Algaroba), Albizia inundata Mart. (Muquem), Geoffroea spinosa Jacq. (Marizeiro), Mimosa pigra L. (Calumbi) and Inga vera subsp. affinis. (DC.) T. D. Penn. (Inga). They suggested various reasons to explain why these species have increased in abundance. For example, P. juliflora is an exotic species that was introduced to the region through recent government actions that have encouraged its cultivation. A. inundata has a high capacity for regrowth, which would explain the increase in the abundance of this species. Respondents also reported that $I$. vera is available in large quantities in the region, but it is not used for timber because it is too tough to use for the construction of houses or as fuel for firewood. Floristic inventory data in this community indicated that the relative density of $I$. vera is high (Table 3 ). Of all the species in the historical graph, respondents indicated a decline only in the abundance of Mimosa tenuiflora (Willd.) Poiret. (Jurema-preta). They explained, "There is little of this plant because the Algaroba killed it; there was more before"; once again, they are referring to the high abundance of $P$. juliflora in the region. Judging by reports from the participants, species such as Copernicia prunifera (Mill.) HE Moore (Carnauba) and Hymenaea courbaril L. (Jatobá) have always existed in low numbers. Respondents even reported that there is only one individual of $H$. courbaril in the nearby riparian community. It is important to note that, according to residents, Ziziphus joazeiro Mart. (Juazeiro) did not exist in the region 20 years ago, and the abundance of this species has increased over the past 10 years. Finally, Mangifera indica L. (Manga), a cultivated species, was one of the most prominent in the free-list and has increased in abundance in the region.

In the floristic surveys performed near the communities, species such as $C$. prunifera and $M$. indica were not found in the inventory, but they were among the ten most important species in the free-lists. However, for species that were part of the floristic surveys, their abundances, as indicated by the representations of respondents, coincided with their relative densities and importance values. For example, I. vera and A. inundata had high relative densities and importance values in the floristic surveys, and during the historical graph construction, respondents represented these species as being of high abundance in the region. $M$. tenuiflora has a low relative density and importance value according to the representations of residents. However, there were also differences between the vegetation inventory data and the representations of residents. For example, the results of the floristic surveys indicated a high relative density of $H$. courbaril despite the fact that residents indicated that it has low abundance in the region today (Table 3).

\subsubsection{Grapiúna community}

Of the ten heads of family interviewed in this community, 70\% affirmed changes in the riparian vegetation while 30\% denied these changes. However, no significant differences were observed between younger and older informants as to whether there had been changes $(\mathrm{p}=0.674$ and Test $\mathrm{G}=0.080$ ). Among those who affirmed changes, $57 \%$ said the changes were for the worse, and $43 \%$ said they were for the better. The central ideas that justified the changes for the worse included deforestation (e.g., 75\% said "the riverbank is now deforested and cleared") or the current predominance of P. juliflora in the area

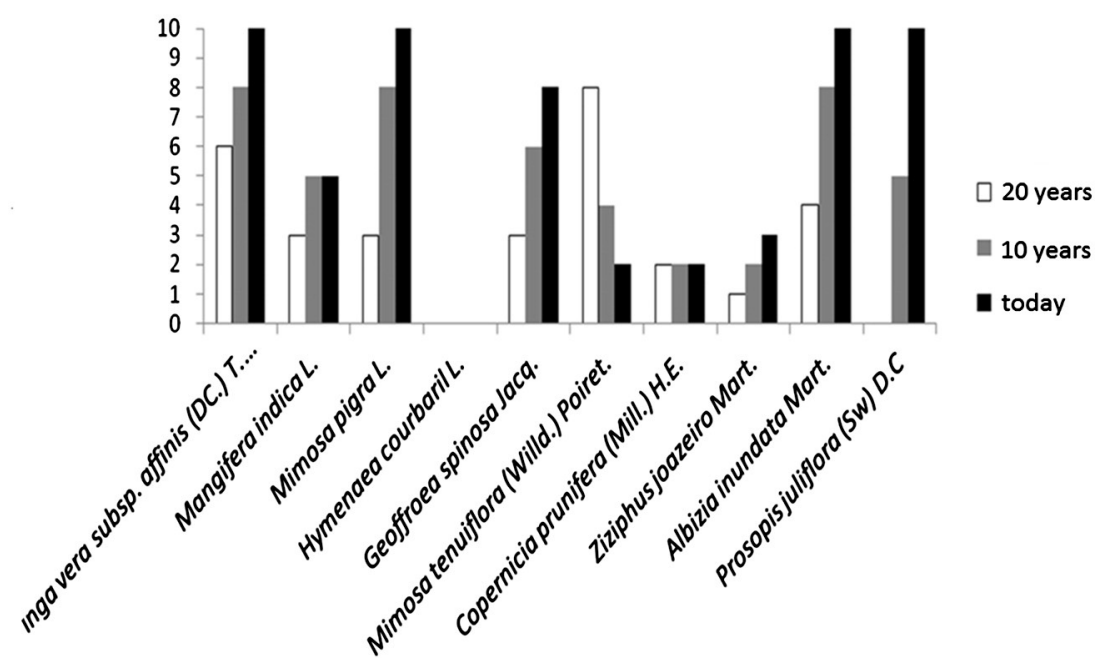

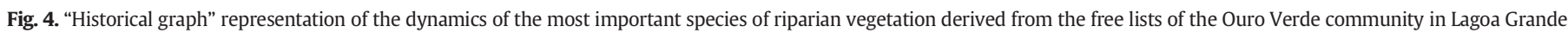
Pernambuco, Northeast Brazil. 
(e.g., "now, there is only Algaroba"). It was then possible to build the following collective subject discourse:

"The riverbank is deforested. Previously, it was full of forests. People have destroyed it. Now, there is only Algaroba."

From the central topics extracted from the key expressions of the respondents' answers, it was possible to observe that there was deforestation in the riparian areas and a predominance of exotic species (P. juliflora) in the region. The most important species from the freelists from this community can be observed in Table 2. According to the vegetation inventory data from Semi-Arid Embrapa, P. juliflora had the highest relative density and importance value (Table 3 ), which coincided with the representations of those interviewed.

Regarding the vegetation changes for the better, informants argued that these were due to the increased abundance of $P$. juliflora and other species in the region. This is illustrated by the following statement: "There is more Algaroba; there are more trees." Additionally, according to the respondents of the semi-structured interviews who viewed the photographs, these changes occurred more than 15 years ago. The photographs chosen most often for the state of the environment 20 years ago were those of the conserved riparian vegetation (50\%), photographs for 10 years ago were those of the semi-degraded areas (50\%), and the most indicated images for today were those of the conserved vegetation (51\%). Again, as for the representations of informants from the Ouro Verde community, residents indicated that the vegetation is regenerating.

Table 2

Useful species of riparian vegetation known to the residents of the Ouro Verde community in Lagoa Grande, PE and the Jatobá and Grapiúna communities in Curaçá, BA in Northeast Brazil. O: Ouro Verde, J: Jatobá and G: Grapiúna.

\begin{tabular}{|c|c|c|c|}
\hline Family/species & $\begin{array}{l}\text { Common } \\
\text { name }\end{array}$ & $\begin{array}{l}\text { Frequency of } \\
\text { citation } \%\end{array}$ & Salience \\
\hline \multicolumn{4}{|l|}{ Anacardiaceae } \\
\hline \multirow[t]{3}{*}{ Mangifera indica $\mathrm{L}$. } & \multirow[t]{3}{*}{ Manga } & $33.3(0)$ & $0.264(0)$ \\
\hline & & $19(\mathrm{~J})$ & $0.131(\mathrm{~J})$ \\
\hline & & $22.2(\mathrm{G})$ & $0.102(G)$ \\
\hline Schinopsis brasiliensis Engl. & Baraúna & $33.3(G)$ & $0.097(G)$ \\
\hline Anacardium occidentale L. & Caju & $22.2(\mathrm{G})$ & $0.13(\mathrm{G})$ \\
\hline Myracroduon urundeuva Allemão & Aroeira & $22.2(\mathrm{G})$ & $0.122(G)$ \\
\hline \multicolumn{4}{|l|}{ Arecaceae } \\
\hline Copernicia prunifera (Miller) H.E. Moore & Carnaúba & $12.5(0)$ & $0.045(0)$ \\
\hline \multicolumn{4}{|c|}{ Leguminosae } \\
\hline \multirow[t]{3}{*}{ Inga vera subsp affinis (DC.) T.D. Penn } & \multirow[t]{3}{*}{ Ingazeira } & $79.2(0)$ & $0.713(0)$ \\
\hline & & $61.9(\mathrm{~J})$ & $0.553(\mathrm{~J})$ \\
\hline & & $100(G)$ & $0.816(G)$ \\
\hline \multirow[t]{3}{*}{ Mimosa pigra L. } & \multirow[t]{3}{*}{ Calumbi } & $20.8(0)$ & $0.121(0)$ \\
\hline & & $61.9(\mathrm{~J})$ & $0.402(\mathrm{~J})$ \\
\hline & & $55.6(G)$ & $0.244(G)$ \\
\hline \multirow[t]{3}{*}{ Hymenaea courbaril L. } & \multirow[t]{3}{*}{ Jatobá } & $16.7(0)$ & $0.146(0)$ \\
\hline & & $33.3(\mathrm{~J})$ & $0.203(\mathrm{~J})$ \\
\hline & & $33.3(G)$ & $0.191(G)$ \\
\hline \multirow[t]{3}{*}{ Geoffroea spinosa Jacq. } & \multirow[t]{3}{*}{ Marizeiro } & $16.7(0)$ & $0.088(0)$ \\
\hline & & $23.8(\mathrm{~J})$ & $0.103(\mathrm{~J})$ \\
\hline & & $22.2(\mathrm{G})$ & $0.065(G)$ \\
\hline Mimosa tenuiflora (Willd.) Poiret. & Jurema-preta & $14.6(0)$ & $0.083(0)$ \\
\hline \multirow[t]{3}{*}{ Prosopis juliflora (Sw) DC. } & \multirow[t]{3}{*}{ Algaroba } & $10.4(0)$ & $0.043(0)$ \\
\hline & & $47.6(\mathrm{~J})$ & $0.268(J)$ \\
\hline & & $88.9(G)$ & $0.731(G)$ \\
\hline \multirow[t]{3}{*}{ Albizia inundata Mart. } & \multirow[t]{3}{*}{ Muquem } & $8.3(0)$ & $0.044(0)$ \\
\hline & & $33.3(\mathrm{~J})$ & $0.177(\mathrm{~J})$ \\
\hline & & $11.1(\mathrm{G})$ & $0.071(G)$ \\
\hline \multicolumn{4}{|l|}{ Rhamnaceae } \\
\hline \multirow[t]{2}{*}{ Ziziphus joazeiro Mart. } & \multirow[t]{2}{*}{ Juazeiro } & $10.4(0)$ & $0.043(0)$ \\
\hline & & $42.9(\mathrm{~J})$ & $0.192(\mathrm{~J})$ \\
\hline \multicolumn{4}{|l|}{ Ulmaceae } \\
\hline Celtis membranaceae Miq & Juaí & $23.8(\mathrm{~J})$ & $0.170(\mathrm{~J})$ \\
\hline \multicolumn{4}{|l|}{ Undetermined } \\
\hline Undetermined 1 & Mangue & $33.3(\mathrm{~J})$ & $0.157(J)$ \\
\hline Undetermined 2 & Capim & $33.3(\mathrm{G})$ & $0.189(\mathrm{G})$ \\
\hline
\end{tabular}

Table 3

Relative densities and importance values of species surveyed in the communities of Ouro Verde in Lagoa Grande, PE and Jatobá and Grapiúna in Curaçá, BA in Northeast Brazil. O: Ouro Verde, J: Jatobá and G: Grapiúna. RD = relative density, IV = importance value.

\begin{tabular}{llll}
\hline Family/Species & $\begin{array}{l}\text { Common } \\
\text { name }\end{array}$ & RD & IV\% \\
\hline $\begin{array}{lll}\text { Anacardiaceae } \\
\text { Schinopsis brasiliensis Engl. }\end{array}$ & Baraúna & $1.1(\mathrm{G})$ & $2.64(\mathrm{G})$ \\
$\begin{array}{l}\text { Myracroduon urundeuva } \\
\text { Allemão }\end{array}$ & Aroeira & $0.47(\mathrm{G})$ & $1.04(\mathrm{G})$ \\
Leguminosae & & & \\
Inga vera subsp affinis & Ingazeira & $16.99(\mathrm{O})$ & $21.52(\mathrm{O})$ \\
$\begin{array}{l}\text { (DC.) T.D. Penn } \\
\text { Mimosa pigra L. }\end{array}$ & Calumbi & $17.96(\mathrm{O})$ & $0.54(\mathrm{G})$ \\
& & $59.8(\mathrm{~J})$ & $27.62(\mathrm{O})$ \\
Hymenaea courbaril L. & Jatobá & $0.49(\mathrm{~J})$ & $1.12(\mathrm{~J})$ \\
Geoffroea spinosa Jacq. & Marizeiro & $14.08(\mathrm{O}) 4.9(\mathrm{~J})$ & $13.45(\mathrm{O}) 11.12(\mathrm{~J})$ \\
Mimosa tenuiflora (Willd.) & Jurema-preta & $0.49(\mathrm{O}) 0.31(\mathrm{G})$ & $0.67(\mathrm{O}) 0.81(\mathrm{G})$ \\
Poiret. & & & \\
Prosopis juliflora (Sw) DC. & Algaroba & $1.46(\mathrm{O}) 1.96(\mathrm{~J})$ & $2.02(\mathrm{O}) 28.71(\mathrm{~J})$ \\
& & $78.62(\mathrm{G})$ & $66.43(\mathrm{G})$ \\
Albizia inundata Mart. & Muquem & $14.56(\mathrm{O})$ & $13.93(\mathrm{O})$ \\
& & $4.41(\mathrm{~J})$ & $4.77(\mathrm{~J})$ \\
& & $1.89(\mathrm{G})$ & $4.09(\mathrm{G})$ \\
Rhamnaceae & & $1.46(\mathrm{O})$ & $2.02(\mathrm{O})$ \\
Ziziphus joazeiro Mart. & Juazeiro & $1.47(\mathrm{~J})$ & $3.35(\mathrm{~J})$ \\
& & $2.2(\mathrm{G})$ & $2.84(\mathrm{G})$ \\
Ulmaceae & & $9.22(\mathrm{O})$ & $8.5(\mathrm{O})$ \\
Celtis membranaceae Miq & Juaí & $4.41(\mathrm{~J})$ & $6.65(\mathrm{~J})$ \\
& & $0.47(\mathrm{G})$ & $1.21(\mathrm{G})$ \\
\hline
\end{tabular}

\subsubsection{Jatobá community}

Finally, in the Jatobá community (Curaçá), 52\% of the 34 heads of family interviewed indicated that the riparian vegetation had changed while $48 \%$ denied that it had changed, and there were no significant differences between younger and older respondents $(p=0.6771$, G-test $=0.7616)$. Among those who said that there were changes, $71 \%$ reported that such changes were for the worse. The following arguments were highlighted from their speeches: "there were more trees in the past" (70\%), "there were more species" (20\%) and "it was more beautiful in the past" (10\%). Thus, the following collective subject discourse was constructed:

"There were more trees; it was deforested when people used it for farming. There were more species. There was more Jurema. It was more beautiful."

From the central topics extracted from the key expressions of the respondents' answers, deforestation in the riparian areas has been observed. According to the semi-structured interviews, such modifications of the landscape occurred over 20 years ago. However, results from the checklist interviews showed that the vegetation was preserved 20 years ago as the images of this environment were indicated the most (49\%). Apparently, changes began 10 years ago based on the respondents' indication of images of semi-degraded vegetation (55\%). Despite indications that the vegetation has been modified, as was observed in the previous two communities, $40 \%$ of respondents acknowledged that the vegetation was conserved based on their choices of images that represent this condition. Informants also reported that agriculture followed an "ebb and flow" (i.e., people grew food for subsistence on the riverbank because, at that time, the advance and retreat of the water was quite regular, but today this practice does not happen due to irregularities in the movement of the São Francisco water). According to residents, after the construction of a large hydroelectric plant in Sobradinho, BA, this agricultural practice became unviable because the dam deregulated the advance and the retreat of the river's water. The construction affected only the residents of this community. 
According to aerial images collected by Semi-Arid Embrapa, 97\% of the city was covered in vegetation 20 years ago followed by a slight reduction in vegetation cover 10 years ago (to 95\%) and an increase in vegetation cover to $97 \%$ today.

The results of the historical graph (Fig. 5) of observed changes in the abundance of the 10 most salient species from the free-list generated by 19 residents ( 10 men and 9 women aged between 20 and 90 years) and from all survey respondents (Table 2 ) indicated that there was a decrease in the abundance of following species: $H$. courbaril, Z. joazeiro, mangrove (unspecified), Celtis membranaceae Miq (Juaí), G. spinosa and $A$. inundata. The informants perceived an increase in the abundance of four species: M. indica, P. juliflora, M. pigra and I. vera. It is noted, therefore, that exotic species such as M. indica, which is grown in the region for commercial purposes, and P. juliflora, which was introduced to the region through recent government actions, are increasing in abundance in the riparian vegetation. The same trend was also observed in the Ouro Verde community.

The floristic data collected in the nearby community (Table 3 ) indicated a high relative density and importance value for M. pigra. According to the representation of the residents from the Jatobá community, there was an increase in the abundance of this species 20 years ago, 10 years ago and today. The relative density and importance values were low for $H$. courbaril as was also observed in the reports for this species from the local population. The relative densities reported in the floristic surveys were low, and according to the representations of respondents, there was also a decrease in abundance for $G$. spinosa, $Z$. joazeiro, and $C$. membranaceae. A. inundata did not have a low relative density and importance value, but residents affirm that its abundance has decreased significantly over time.

\subsection{Locally represented historical events that influenced riparian vegetation change}

During the semi-structured interview in Ouro Verde, 58\% of respondents mentioned agriculture as the factor most responsible for changes for the worse in the riparian vegetation. They explained that the "ebb and flow" type of agriculture was highly destructive to the vegetation. However, informants also indicated that timber extraction (16\%), increased urbanization (16\%) and dam construction (10\%) damaged the riparian vegetation. Among those who said that the riparian vegetation had changed for the better, $57 \%$ attributed responsibility for this change to a recent environmental education project in the region. Twenty-five percent reported that it occurred due to increased restrictions on land use, and $18 \%$ said that the vegetation failed to grow on the riverbank. Through the participatory timeline construction method (Table 4), informants were encouraged to represent the historical events that were actually responsible for altering the landscape. However, they spontaneously restricted the events to those that somehow improved the quality of life of the people in the community. The interpretations of the environmental changes were performed by the researchers. In Grapiúna community, which did not construct the timeline, it was possible to verify the events that were possibly responsible for landscape modification through the semi-structured interviews. Seventy percent of respondents who said that the vegetation has changed for the worse attributed responsibility for these changes to the system of farming in the region, and the other $30 \%$ said that these changes were caused by logging. They argued that, following the abandonment of this type of agriculture, the vegetation improved. As previously noted in Jatobá community, the riparian vegetation in the study area changed for the worse according to $71 \%$ of the informants. Of these, $75 \%$ attributed responsibility for these changes to agriculture. However, among the four people who said that the vegetation has changed for the better, three stated that these changes occurred precisely because of the changes in the agricultural system.

In that same community, a timeline (Table 5 ) was constructed by 15 respondents during a second stage of the participatory methodology. The timeline complements the semi-structured interviews concerning the factors responsible for environmental and/or riparian vegetation changes over time.

The timeline showed that there were three floods in the region; however, only the flood in 1979 destroyed riparian vegetation. Another event that caused the destruction of riparian vegetation in the region was agriculture as observed from the results of the semi-structured interviews mentioned above. The population reported that agriculture in the region was of the "ebb and flow" type for approximately 28 years. A departure from this type of agricultural system most likely improved the situation for riparian vegetation because farmers were forced to cultivate areas away from the riverbank. This can be inferred from the semi-structured interviews regarding the changes for the better in the vegetation. Participants also noted other events that were possibly responsible for changes in the landscape. For example, the arrival of electricity to this area destroyed the Caatinga as this allowed for irrigated agriculture in areas far from the river. It is important to note that what the respondents called Caatinga did not refer to riparian vegetation

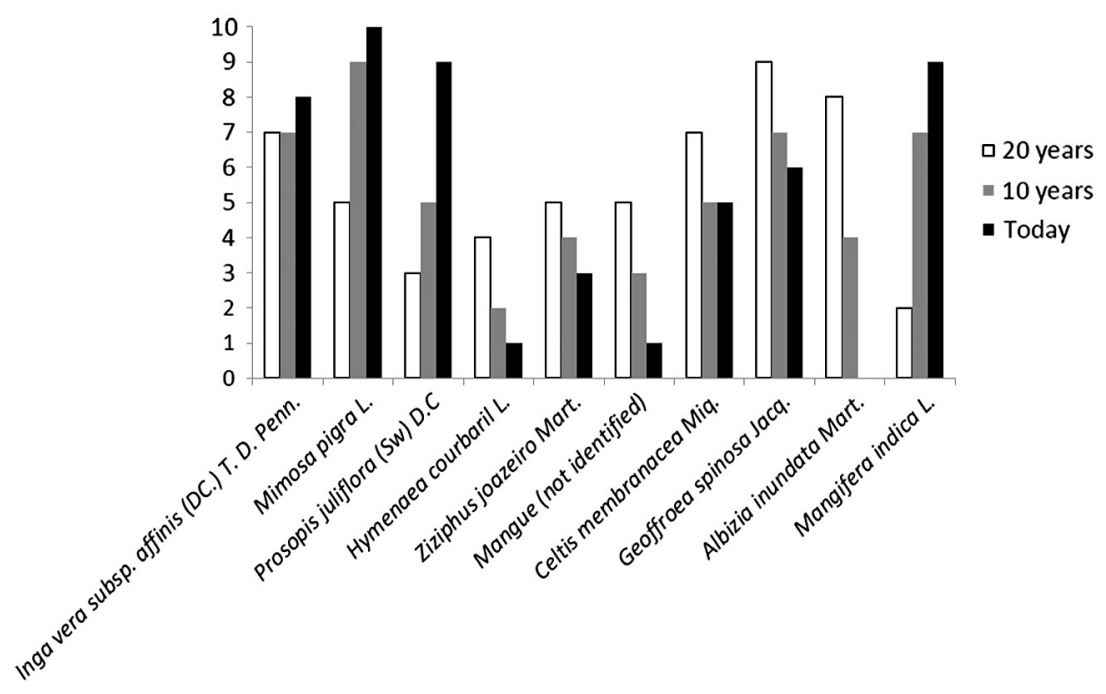

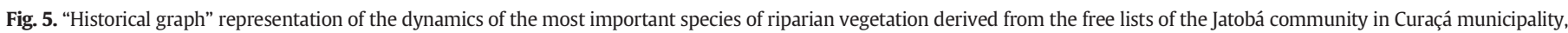
Bahia, Northeast Brazil. 
Table 4

"Timeline" of the historical events that changed the landscape in the Ouro Verde community, Lagoa Grande, PE, Brazil.

\begin{tabular}{lll}
\hline Year & Event & Consequence \\
\hline 1995 & Community foundation & $\begin{array}{l}\text { Not represented } \\
\text { Facilitated the transportation of grapes } \\
\text { grown by the community }\end{array}$ \\
1996 & Arrival of energy & $\begin{array}{l}\text { Improved the life quality of people in the } \\
\text { community }\end{array}$ \\
\hline
\end{tabular}

but to areas far from the riverbank. It was clear to most participants that riparian vegetation extends to $500 \mathrm{~m}$ from the riverbank, and this finding is consistent with the Brazilian Forest Code.

\subsection{Representations of the utility and conservation of riparian vegetation}

Residents of Ouro Verde community were first asked if the riparian vegetation was of use to them, and $90 \%$ answered in the affirmative. The major uses highlighted were preserving the river (52\%), irrigated agriculture (13\%) (because these informants claim that the forest protects the river water and consequently provides water for irrigated agriculture), preserving the environment (13\%), medicinal uses (7\%) and other uses (15\%). Other uses referred to timber and leisure.

When asked for their opinions about whether the riparian vegetation should be conserved, $99 \%$ answered positively. According to the representations of these respondents, those who should be responsible for the conservation of the riparian vegetation are everyone (65\%), people living near the riparian vegetation (20\%), government agencies such as IBAMA (13\%) and owners of land near the riparian vegetation (2\%). This shows that respondents are willing to contribute to the conservation of riparian vegetation, and most of them think that it is everyone's duty to conserve it. Moreover, they noted possible solutions for the rehabilitation of these areas such as stopping deforestation (35\%), promoting reforestation (28\%), taking care of the forest by pruning trees and fertilizing (15\%), and engaging in environmental education (13\%). The others (9\%) answered that the vegetation should be left as it is today.

All of the respondents from Grapiúna community replied that the riparian vegetation was of some use and should be preserved. Among the main reasons why it should be conserved included the preservation of the river (40\%) and survival (30\%). When they were questioned about who would be responsible for the conservation of riparian vegetation, $50 \%$ attributed this responsibility to all people, $30 \%$ said that it was the responsibility of people who lived near the riparian vegetation, and $20 \%$ attributed this responsibility to government agencies.

These respondents also indicated that the main solutions for the conservation of riparian vegetation were stopping deforestation (60\%) followed by reforestation (20\%) and increased surveillance (20\%). Similar to the results above, most of the 23 heads of family in the Jatobá community (91\%) stated that the riparian vegetation should be

\section{Table 5}

"Timeline" of the historical events that changed the landscape in the Jatobá community, Curaçá, BA, Brazil.

\begin{tabular}{lll}
\hline Year & Event & Consequence \\
\hline 1909 & Community foundation & Not represented \\
1960 & Flood & Not represented \\
1976 & Dam construction & Agriculture has advanced to the caatinga \\
1979 & Flood & Riparian vegetation destruction \\
1980 & Irrigation & Increased agriculture \\
1982 & Agriculture & Riparian vegetation deforestation \\
1988 & Agriculture mechanization & Increased pollution by pesticides \\
1992 & Electrification & Caatinga destruction \\
1992 & Flood & Formation of a small village in the community \\
1998 & Training course & Awareness of the population regarding forest \\
& & destruction \\
\hline
\end{tabular}

conserved. The main reasons for conservation were preserving the river (30\%), enjoying nature (30\%), and other issues such as preventing global warming, attracting rain and decreasing pollution.

When encouraged to report on who would be responsible for the conservation of the riparian vegetation, the majority of the respondents $(80 \%)$ said that it was everyone's duty. Among the main solutions suggested were reforestation, stopping deforestation and environmental education.

\subsection{Similarities and differences between environmental representations in} the communities studied

There were no statistically significant differences between people who said that the vegetation has changed for the better or for the worse ( $p=0.177, \chi^{2}=2200$ ). In Ouro Verde and Jatobá, the participants' representations suggested that there was most likely an increase in the abundance of exotic species and a decrease in the abundance of native species. In all three communities, agriculture was considered to be a factor responsible for altering the vegetation. These changes likely occurred 10 years ago. During the timeline construction in Jatobá, participants also pointed to agriculture as the predominant factor in vegetation change. This methodology did not obtain the same results in Ouro Verde, despite having been applied in the same way as in the Jatobá community because these people noted only historical events that improved their quality of life and not the events that changed the landscape.

Participants from the three communities were concerned about the conservation of riparian vegetation mainly because they knew that it protects the river. This can be observed in their responses to questions about who is responsible for the conservation of the vegetation. The majority responded that everyone is responsible and noted that stopping deforestation could be a solution for environment conservation even though they recognize themselves as agents that modify the landscape.

\section{Discussion}

\subsection{Representations of local changes in riparian vegetation}

The representations of residents from the three communities indicated that there were changes in the riparian vegetation of the region. However, there was no clear agreement as to whether changes were considered for the better or for the worse, especially among Grapiúna and Ouro Verde respondents. This suggests that because these two communities are rural settlements prohibited from using native vegetation, respondents may have felt inhibited from indicating that there was a change for the worse in the riparian vegetation. This reflection is supported by discourse from the Ouro Verde community indicating that local people destroyed the forest thus exempting them from liability (for example, "People destroyed it for planting", instead of saying "we destroyed the forest"). However, it is possible that this type of discourse does not reflect peoples' real attitudes about what was observed. In the social sciences, it is argued that this type of discourse is the result of ideological issues (e.g., ideas, thoughts, judgments and values) that are socially constructed (Van Dijk, 2008). However, these ideologies become conflicted when social groups are forced to use environmental resources to meet their daily survival needs. A methodology is required that allows for deeper analysis of the local situation in relation to the real attitudes of the informants about riparian vegetation. We also believed that our roles as researchers, which combined with time limitations, did not allow for the establishment of trust with the informants and may have inhibited them from revealing their real relationship with the riparian vegetation because they often associate scientific research with environmental control agencies.

The representations of changes for the better in the riparian vegetation must also be taken into consideration. These representations corroborate the vegetation coverage data collected by Semi-Arid Embrapa, 
which indicate a $1.32 \%$ increase in vegetation cover in the municipality of Lagoa Grande from the decade of 1990 to the present. This fact emphasizes the idea that studies of local representations are important for the diagnosis and recovery of degraded areas (Tabuti, 2007; Lykke, 2000). This improvement in the vegetation perceived by respondents may be a result of an environmental awareness project sponsored by Embrapa in the Ouro Verde and Jatobá communities in 2008. If so, this program may have induced informants to better conserve the vegetation as illustrated by the statement: "They are protecting more and are planting more plants." This can also be observed in the perceived increase in $P$. juliflora from the floristic survey in the Grapiuna community and by the fact that this increase was highlighted as beneficial. Investigations of environmental representations are highly complex as each individual perceives, reacts and responds differently to actions affecting the environment (Faggionato, 2001).

The data obtained in the Ouro Verde and Jatobá communities indicated that the changes in riparian vegetation began 20 years ago, and the data obtained through the checklist interviews indicated changes occurring 10 years ago. This divergence of results was expected because, according to Neiva-Silva and Koller (2002), some people have difficulty verbally expressing their representations, and the use of photographs facilitates the expression of representations of the environment. Therefore, some environmental studies make use of checklist interviews. However, it is important to note that most checklist interviews are used to verify the preferences and priorities of the informants regarding a particular landscape (Gómez-Limón and Fernández, 1999; Hagerhall, 2001) and not to verify perceptions of landscape change as in this study. Therefore, that the methodologies used in studies of environmental representations influence data collection and that such research has great complexity. Importantly, using this tool had some methodological limitations as the researchers' choice of images represented gradients of landscapes degraded and not degraded. This fact may have influenced the informants' interpretations because some of them indicated the conserved landscape without taking into account whether the floristic composition was represented by native or exotic species. However, in terms of triangulating results and stimulating insights, this tool proves to be important.

In the statements by informants, it was possible to verify riparian vegetation species that existed previously but are no longer present today. The results of the historical graphs from the Ouro Verde and Jatobá communities indicated which of the 10 most prominent species on the free-list experienced changes in relative abundance 20 and 10 years ago and today. The apparent decline of some species common in the riparian vegetation, such as $H$. courbaril, C. membranaceae, and A. inundata (see Ferraz et al., 2006), was clear. The results also showed the likely increase in the abundance of exotic species, such as P. juliflora, as a result of government actions to encourage their cultivation. These species compete with native species and severely affect the diversity of the environment (Maundu et al., 2009). These results corroborate floristic surveys that indicated a low relative density of A. inundata and other species, such as $H$. courbaril and C. membranaceae, that were part of the community's inventory. This finding emphasizes the importance of accessing local representations of vegetation for reforestation projects. $M$. indica is believed to have great importance as a food source for the local population, which is a result similar to that obtained in the work of Wezel and Haigis (2000). These data reinforce the argument that the participation of local communities in conservation strategies is of the utmost importance because such information may be useful for the replanting of native species. Authors such as Lykke (2000) and Xu et al. (2006) have also demonstrated that the perceptions of local populations regarding vegetation, including their indication of the decline of some species, make it possible to identify changes in the landscape. These data are very useful for future reforestation projects in the region. Below we will explain to what extent the local people are willing to contribute to vegetation recovery.
4.2. Locally represented historical events that influenced changes in riparian vegetation

Agriculture was identified as the main cause of vegetation change by respondents. This result is similar to that of Kangalawe (2009) who worked with farmers in Tanzania. Those farmers indicated that there was a decrease in natural vegetation due to erosion caused by agricultural activities in that region. However, the agricultural cause for the modification of vegetation in the present study was not erosion but rather the "ebb and flow" type of agriculture described above. In another study, people attributed landscape change not to human actions but to environmental factors, such as the lack of rain; however, these data do not agree with the meteorological data for the region (Katijua and Ward, 2008).

Regarding the timeline in the Jatobá community, other factors in addition to agriculture were considered to be causes of landscape change, a great flood for example. However, the timeline construction in the Ouro Verde community did not verify the historical events that caused landscape modification but addressed only those related to improving quality of life. This may be because $90 \%$ of the respondents were from other cities and may not have developed ties to the environment sufficient to observe such changes. This fact could be explained by the statement of Tuan (1980) that much of what is perceived must have value for the biological survival of the individual. Maroti et al. (1998) argue that it is difficult to detect how social groups perceive their environments. These issues may present difficulties for future projects that aim to access this information for the conservation of riparian vegetation in the region.

\subsection{Representations of aspects related to the use and conservation of riparian vegetation}

When asked about those responsible for the conservation of riparian vegetation, informants from the three communities believed that everyone is responsible. This response indicates that respondents are likely to participate in future projects related to conservation in this area. A related example is of a successful project that was carried out with farmers in Europe where those most interested in forest conservation were invited to participate in a workshop for forest planning and conservation and provide feedback regarding their perceptions of the area (Bayfield et al., 2008). In another study, farmers who had been excluded from a reforestation project in Ireland responded negatively to the project (Dhubháin et al., 2009).

In this study, several factors related to the survival of the participants justified their concern for the conservation of riparian vegetation. Most respondents replied that they conserved riparian vegetation to protect the river. It shows that the informants probably associate conservation of riparian vegetation to the river maintenance. There was concern for its importance to the irrigated agriculture that sustains the riverine families. Moreover, because this is a Caatinga ecosystem with strict climatic seasonality and irregular distribution of rainfall (restricted to three to four months per year) (Araújo et al., 2007), the water resources in the São Francisco River are extremely important to the survival of the local population. This finding corroborates the position of Soliva and Hunziker (2009) who maintain that when people evaluate the landscape, they are influenced by values, personal interests and life situations. However, it was also possible to detect affective links between the informants and the riparian environment in this study. Wilson (1989) termed this biophilia and defined it as a connection between human beings and other life forms. There are also those who advocate the preservation of riparian vegetation for its scenic beauty. This can be explained by Tuan (1980) who claims that links between individuals and the environment are triggered by simple visual pleasure. These results illustrate the complexity of investigations of environmental representations, which must contend with a diversity of thoughts, interests and worldviews. 


\section{Final considerations}

This study showed that, according to informants' perceptions, the riparian vegetation has been modified. However, some informants perceived that the vegetation has changed for the better while others indicated that these changes were for the worse, but linked to this perception of the positive aspects of landscape change was an increase in the abundance of exotic species cultivated for agricultural purposes. This demonstrates that native species may have been replaced over time by exotic species of economic importance, such as $M$. indica.

It turns out that there are advantages and disadvantages to making use of different methodological tools to access perceptions. For example, in the semi-structured interview, informants claimed that riparian vegetation has changed for the better, but it was noted that these perceptions were associated with increased abundance of exotic and cultivated species in the historical graph. Therefore, the triangulation of methods for better interpretation of results is important.

Another aspect that deserves mention is that one of the main factors identified as causative agents of environmental change in the region were farming practices; informants acknowledged that these activities brought about a change for the worse of vegetation.

It was notable that the main concern of the population was for the San Francisco River to the detriment of the riparian vegetation. For example, the population is not concerned with riparian vegetation by itself but with its role in the protection of the river. However, surely the fact that the vast majority of respondents are willing to contribute to the revitalization of riparian vegetation is of great importance for the future of this ecosystem and the revitalization project proposed by Semi-Arid Embrapa. In addition, informants indicated by historical graph the useful species in decline according to their perceptions, and this indicates the species that should be prioritized for replanting. The odds of success will be greater because the project will involve the local population, will not be exclusively top-down and will take into account the local needs and uses of the species. The use of participatory methods reinforces this idea, since it helps in empowering local populations by providing a collective reflection on their own reality.

Finally, it is noteworthy that despite the methodological limitations and diversity of information accessed related to the processes of landscape modification, the study showed that people who interact with the natural environment are able to perceive their role and may be willing to contribute to conservation. However, these perceptions can be skewed by several factors, such as socioeconomics or an individual's relationship with the environment among others, which deserve to be better investigated in other studies. It is also recommended that future research on this area uses more specific questions, such as what the participants consider as a change for the better or the worse, in order to obtain more robust information on the subject. Furthermore, it is believed that the use of images that accurately represent changes in riparian vegetation abundance and diversity over time can help respondents to better recognize landscape modifications. Finally, we emphasize that separately analyzing perceptions according to respondents' socioeconomic variables facilitates result interpretation and discussion, given that, for example, those with higher income and the elders have different perceptions regarding landscape modifications. Thus, for a deeper investigation on this subject, the above factors should be taken into account.

\section{Acknowledgments}

The authors thank the residents of the communities who participated in the study. We also thank Semi-Arid Embrapa and its project, "Diagnosis of degraded areas and pilot plan for the restoration of the São Francisco riverbank in the Caatinga Biome", for financial and logistical support, and we thank the trainees Mara Poline and Ùldérico Rios for their assistance with data collection. We thank CNPq for the scholarship granted to the first author and for the financial support and research productivity scholarship awarded to U.P. Albuquerque. To finish this paper, we also had the support of the "Rede de Investigação em Biodiversidade e Saberes Locais" (REBISA - Research Network on Biodiversity and Local Knowledge), with financial support from the FACEPE (Foundation for Support of Science and Technology) to the project "Núcleo de Pesquisa em Ecologia, conservação e Potencial de Uso de Recursos Biológicos no Semiárido do Nordeste do Brasil" (Center for Research in Ecology, Conservation and Potential Use of Biological Resources in the Semi-Arid Region of Northeastern Brazil-APQ-1264-2.05/10).

\section{References}

Albuquerque, U.P., Ramos, M.A., Lucena, R.F.P., Alencar, N.L., 2014. Methods and Techniques Used to Collect Ethnobiological Data. In: Albuquerque, U.P., Cunha, L.V.F.C. Lucena, R.F.P., Alves, R.R.N. (Eds.), Methods and Techniques in Ethnobiology and Ethnoecology. Springer, pp. 15-38.

Araújo, E.L., Albuquerque, U.P., Castro, C.C., 2007. Dynamics of Brazilian caatinga - a review concerning the plants, environment and people. Funct. Ecosyst. Commun. 1, $15-29$.

Ayres, M., Ayres, JrM, Ayres, D.L., Santos, A.A., 2007. BioEstat: aplicações estatísticas nas áreas das ciências biológicas e médicas Sociedade Civil Mamirauá, Brasil (364pp.).

Bayfield, N., Barancok, P., Furger, M., Sebastiá, M.T., Domínguez, G., Lapka, M., Cudlinva, E., Vescovo, L., Ganielle, D., Cernusca, A., Tappeiner, U., Drösler, M., 2008. Stakeholder perception of the impacts of rural funding scenarios on mountain landscapes across Europe. Ecosystem 11, 1368-1382.

Bell, S., 2001. Landscape pattern, perception and visualisation in the visual management of forests. Landsc. Urban Plan. 54, 201-211.

Borgatti, S.P., Natick, M.A., 1996. Analytic technologies. Antrhopac 4

Campello, F.B., Gariglio, M.A., Silva, J.A., Leal, A.M.A., 1999. Diagnóstico florestal da região Nordeste IBAMA/PNUD/BRA/93/033, Brasil (20 pp.).

Cavalcante, S., Maciel, R.H., 2008. Métodos de avaliação da percepção ambiental. (149-180) In: Pinheiro, J.Q., Günther, H. (Eds.), Métodos de pesquisa nos estudos pessoa-ambiente. Casa do psicólogo, São Paulo, pp. 27-41.

Dhubháin, Á.N., Fléchard, M., Moloney, R., O'Conno, D., 2009. Stakeholders' perceptions of forestry in rural areas-two case studies in Ireland. Land Use Policy 26, 695-703

Faggionato, S., 2001. Percepção ambiental. Disponível em www.educar.sc.usp.br/textos (Acessado em 20/11/2009).

Fernandes, R.S., Viegas, R., Guanandy, J.V., 2006. Avaliação do perfil de cidadania de estudantes do ensino médio-técnico do CEFET-RJ. Revista Eletrônica do Mestrado em Educação Ambiental 17, 195-213.

Ferraz, J.S.F., Albuquerque, U.P., Meunier, I.M.J., 2006. Valor de uso e estrutura da vegetação lenhosa às margens do Riacho do Navio, Floresta, Pernambuco. Acta Bot. Bras. 20, 1-10.

Gómez-Limón, J., Fernández, J.V.L., 1999. Changes in use and landscape preferences on the agricultural-livestock landscapes of the central Iberian Penisula (Madrid, Spain). Landsc. Urban Plan. 44, 165-175.

Gumuchian, H.E., Marois, C., 2000. Initiation a la recherche en géographie, aménagement, développement territorial, environnement. Anthropos, Paris (Montreal: Presses de l'Université de Montréal).

Hagerhall, C.M., 2001. Consensus in landscape preference judgements. J. Environ. Psychol. $21,83-92$

Instituto Brasileiro de Geografia e Estatística (IBGE), 2008. Available in http://www. ibge.gov.br (Accessed may 20 from 2009).

Kangalawe, R.Y.M., 2009. Changing land use/cover patterns and implications for sustainable environmental management in the Irangi Hills, central Tanzania. Environ. Dev. Sustain. 12, 449-461.

Katijua, M., Ward, D., 2008. Pastoralists' perceptions and realities of vegetation change and browse consumption in the northern Kalahari, Namibia. J. Arid Environ. 69, $716-730$.

Lefevre, F., 2005. Depoimentos e discursos: uma proposta de análise em pesquisa socialLiber Livro (255 pp.)

Lykke, A.M., 2000. Local perceptions of vegetation change and priorities for conservation of woody-savanna vegetation in Senegal. J. Environ. Manage. 59, 107-120.

Maroti, P.S., Santos, J.E., Pires, J.S.R., 1998. Caracterização perceptiva de uma Área Natural de Conservação por Docentes do Ensino Fundamental. Rev. Univille. 3, 55-65.

Maundu, P., Kibet, S., Morimoto, Y., Imbumi, M., Adeka, R., 2009. Impact of Prosopis juliflora on Kenya's semi-arid and arid ecosystems and local livelihoods. Biodiversity 10 (2009), 33-50.

Minayo, M.C.S., 1993. O desafio do conhecimento científico: pesquisa qualitativa em saúde, 2 edição. Hucitec-Abrasco, São Paulo/Rio de Janeiro.

Neiva-Silva, L., Koller, S.H., 2002. O uso da fotografia na pesquisa em Psicologia. Estudos de Psicologia, São Paulo pp. 237-250.

Santiago, A.G., Bianchi, M.F., Feitosa, F.F., Rosa, M.M., 2002. Diferentes níveis de percepção da paisagem da lagoa da conceição (SC) através do SIG. Paisagem e ambiente- ensaio, 14, pp. 171-186.

Sheil, D., Puri, R.K. Basuki, I., Heist, M.V., Wan, M., Liswanti, N., Sardjono, M.A., Samsoedin, I., Sidiyasa, K., Angi, E.M., Gatzweiler, F., Jonhson, B., Wijaya, A., 2004. Explorando la biodiversidad, el medio ambiente y las perspectives de los pobladores en areas boscosas: métodos para la valoración multidisciplinaria del paisage, 2 ed. CIFOR, Bogor (93 pp.).

Sieber, S.S., Silva, T.C., Campos, L.Z.O., Zank, S., Albuquerque, U.P., 2014. Participatory Methods in Ethnobiological and Ethnoecological Research. In: Albuquerque, U.P., Cunha, L.V.F.C., Lucena, R.F.P., Alves, R.R.N. (Eds.), Methods and Techniques in Ethnobiology and Ethnoecology. Springer, pp. 39-48. 
Soliva, R., Hunziker, M., 2009. Beyond the visual dimension: using ideal type narratives to analyse people's assessments of landscape scenarios. Land Use Policy 26, 284-294.

Tabuti, J.R.S., 2007. The uses, local perceptions and ecological status of 16 woody species of Gadumire Sub-county, Uganda. Biodivers. Conserv. 16, 1901-1915.

Tuan, Y., 1980. Topofilia um estudo da percepção, atitudes e valores do meio ambiente. Difel, Difusão editorial S.A. São Paulo (288 pp.).

Van Dijk, T.A., 2008. Semántica del discurso e ideologia. Discurso \& Sociedade pp. 201-261.
Wezel, A., Haigis, J., 2000. Farmers' perception of vegetation changes in semi-arid Niger. Land Degrad. Dev. 1, 523-534.

Wilson, E.O., 1989. Biofilia. Fondo de Cultura Económica, México (283pp.).

$\mathrm{Xu}$, J., Chen, L., Lu, Y., Fu, B., 2006. Local people's perceptions as decisions support for protected area management in Wolong Biosphere Reserve, China. J. Environ. Manage. 78, 362-372. 